\title{
Interactive pedagogical tools could be helpful for medical education continuity during COVID-19 outbreak
}

\author{
L'intérêt des outils de pédagogie interactive pour la continuité \\ de la formation médicale durant l'épidémie de Covid-19
}

\author{
Guillaume Grzych 1,2,3 \\ Susanna Schraen-Maschke 2,4,5 \\ 1 University of Lille, Faculty of \\ pharmaceutical and biological sciences, \\ Lille, France \\ ${ }^{2} \mathrm{CHU}$ Lille, Laboratory of biochemistry, \\ biology and pathology center, Lille, \\ France \\ ${ }^{3}$ Inserm, UMR-1011-European \\ genomic institute for diabetes, \\ Institut Pasteur de Lille, \\ Université de Lille, France \\ ${ }^{4}$ University of Lille, Faculty of medicine, \\ Lille, France \\ ${ }^{5}$ Inserm, UMR 1172, JPArc, \\ Faculté de médecine, \\ Université de Lille, France
}

\begin{abstract}
Training and education are essential for medical students. During the COVID-19 outbreak, numerous schools and universities have had to close. Ensuring pedagogical continuity requires alternatives to the traditional classroom, especially in medical education. Usual distance learning tools such as videos and downloadable handouts are not sufficient to promote efficient teaching. Distance learning requires self-motivation and does not give you direct access to your instructor. Some students fear the loss of human contact with an instructor - like asking questions during and after class - which promotes learning, understanding and communication. Moreover, classical distance learning methods do not offer immediate feedback that can help students in their understanding of the lecture. In this context, interactive pedagogic tools (IPT) could be useful for medical education continuity and for maintaining human contact necessary in pedagogy. We briefly evaluated interactive pedagogic tool compared to traditionnal distancial tools on medical students. This study showed the importance to have direct contact with a teacher and feedback during a lecture and to not exclusively perform distance learning without direct interaction and feedback. Hence, in the present context, we encourage teacher to use this type of tools to maintain direct interaction with students - which is essential in pedagogy - and ensure a qualitative pedagogical continuity.
\end{abstract}

Key words: medical education continuity, online interactive pedagogy tools, active distance learning, audience response system

Résumé. La formation et l'éducation sont essentielles pour les futurs praticiens en santé. Pendant l'épidémie de Covid-19, de nombreuses universités ont dû fermer. Pour assurer une continuité pédagogique, des alternatives ont dû être rapidement mises en place. Cependant, les outils classiques d'apprentissage à distance, tels que les vidéos et les polycopiés téléchargeables, ne suffisent pas pour assurer un enseignement efficace. L'apprentissage à distance exige une auto-motivation de la part de l'étudiant et ne donne pas un accès direct à l'enseignant. La perte de contact humain est un frein majeur à la compréhension et à la pédagogie. Dans ce contexte, les outils de pédagogie interactives pourraient être utiles pour la continuité de l'enseignement médical en maintenant les contacts humains nécessaires. Nous avons donc évalué ces outils interactifs comparés aux autres modes traditionnels d'enseignement à distance sur un groupe d'étudiants en santé. Nos résultats montrent l'importance d'avoir un contact direct avec un enseignant et un retour d'information pendant l'enseignement et que dispenser exclusivement un enseignement à distance sans interaction est néfaste pour la pédagogie. C'est pourquoi, dans le contexte actuel, 
nous encourageons les enseignants à utiliser ce type d'outils pour maintenir une interaction directe avec les étudiants afin d'assurer une continuité pédagogique qualitative.

Mots clés : continuité pédagogique, pédagogie interactive, enseignement à distance, pédagogie médicale, système de réponse interactif

Training and education are essential for medical students, especially in laboratory medicine [1]. During the COVID19 outbreak, numerous schools and universities have had to close. Ensuring pedagogical continuity requires alternatives to the traditional classroom, especially in medical education [2]. Usual distance learning tools such as videos and downloadable handouts are not sufficient to promote efficient teaching [3]. Distance learning requires self-motivation and does not give you direct access to your instructor. Some students fear the loss of human contact with an instructor - like asking questions during and after class - which promotes learning, understanding and communication [4]. Moreover, classical distance learning methods do not offer immediate feedback that can help students in their understanding of the lecture.

In this context, interactive pedagogic tools (IPT) could be useful for medical education continuity and for maintaining human contact necessary in pedagogy. Recent studies showed that IPT such as audience response systems (ARS) promote active learning by improving understanding and participation during class. In our last study, we evaluated interactive pedagogic tools and one of these new tools (Wooclap) is able to generate different activities, such as multiple choice questions, polls, open questions, matchings, and many others [5]. Moreover, students can answer to question activity or ask directly question to teacher during classroom through a message server; Such tools are usually used live during the lecture, but by combining them with a webinar audio system and sharing their screen (e.g. BigBlueButton, Zoom, Youtube Live...), teachers can give a lecture and interact with students through online activities, as previously described [5].

We briefly evaluated this tool (Wooclap associated to Zoom session) during a 3-hour lecture with 64 students. Considering material needs, students needed two screens to participate (one for the webinar session and one for the IPT session): 55\% used a computer (for the Zoom session) combined with a smartphone (for the Wooclap session), $35 \%$ used a computer with one screen and different tabs on a web browser, and $10 \%$ used a computer with two separate screens. After the lesson, a short online survey of 9 questions based on our last study was submitted to the students (table 1). 62 of 64 Students completed the online survey (97\% survey response rate). Survey results are shown in table 1 and were analyzed by mean $+/$ - standard deviation (SD).

Table 1. Student survey, results and meaning of different scales used $(n=62)$.

\begin{tabular}{|c|c|c|c|c|}
\hline Question & & 0 & 10 & $\begin{array}{l}\text { Results } \\
\text { (mean +/- SD) }\end{array}$ \\
\hline \multicolumn{5}{|c|}{ Pedagogic aspect } \\
\hline Question 1 & Evaluate help to memorize during classroom & $\begin{array}{l}\text { Not helpful } \\
\text { to memorize }\end{array}$ & $\begin{array}{l}\text { Very helpful } \\
\text { to memorize }\end{array}$ & $7.6 \pm 2.1$ \\
\hline Question 2 & Evaluate your active participation during classroom & I did not participate & I participated a lot & $8.5 \pm 1.6$ \\
\hline Question 3 & Evaluate the understanding during classroom & $\begin{array}{l}\text { Does not improve } \\
\text { understanding }\end{array}$ & $\begin{array}{l}\text { Improves totally } \\
\text { understanding }\end{array}$ & $8.1 \pm 1.8$ \\
\hline Question 4 & $\begin{array}{l}\text { Does the format allow you to ask and answer } \\
\text { to some questions during the session? }\end{array}$ & Not agree & Totally agree & $8.1 \pm 2.6$ \\
\hline Question 5 & Does this tool encourage you to attend the course? & Not agree & Totally agree & $9.3 \pm 1.0$ \\
\hline Question 6 & $\begin{array}{l}\text { Does the format make it possible to point essential } \\
\text { notions to the lessons? }\end{array}$ & Not helpful & Very helpful & $8.7 \pm 1.4$ \\
\hline \multicolumn{5}{|c|}{ Comparison with other distance learning tools } \\
\hline Question 7 & $\begin{array}{l}\text { Provides an advantage compared with completely } \\
\text { de-materialized lessons such as handouts } \\
\text { or online videos }\end{array}$ & Not agree & Totally agree & $9.0 \pm 1.6$ \\
\hline Question 8 & $\begin{array}{l}\text { Provides an advantage compared } \\
\text { with webinar lecture without interactive activities }\end{array}$ & Not agree & Totally agree & $9.0 \pm 1.2$ \\
\hline \multicolumn{5}{|l|}{ Global } \\
\hline Question 9 & In general, note the tool on a scale of 1 to 10 & Bad & Good & $8.8 \pm 1.1$ \\
\hline
\end{tabular}


First, this new evaluation showed results similar to our previous study for pedagogy parts (table 1, Questions 1 to 6), meaning that using IPT from a distance rather than face-toface does not undermine the general benefits of these tools. Overall, our evaluation showed that remote use of IPT is appreciated by students and helps them to learn, understand, and remember essential notions of the lecture. In addition, students can use them easily on their first try. As previously described, IPT Wooclap allows students to ask questions directly through the tool, and the teacher could answer immediately. Secondly, the second part of the survey (table 1, Questions 7 to 8) showed that use of IPT is beneficial compared with other offline teaching methods, such as recorded videos and online handouts. Moreover, this result also showed the benefits of using IPT compared with live video sessions without interactive pedagogic tools.

This brief report again showed the importance to have direct contact with a teacher and feedback during a lecture and to not exclusively perform distance learning without direct interaction and feedback. Hence, in the present context, we encourage teacher to use this type of tools to maintain direct interaction with students - which is essential in pedagogy and ensure a qualitative pedagogical continuity.

Conflict of interest: none of the authors has any conflict of interest to disclose concerning this article.

\section{Références}

1. Guidi GC, Lippi G. Undergraduate education in laboratory medicine. Clin Chim Acta 2008 ; $393: 9-12$.

2. Gallo G, Trompetto M. The Effects of COVID-19 on academic activities and surgical education in Italy. J Invest Surg 2020 [Ahead of print].

3. McLaughlin JE, Rhoney DH. Comparison of an interactive e-learning preparatory tool and a conventional downloadable handout used within a flipped neurologic pharmacotherapy lecture. Curr Pharm Teach Learn $2015 ; 7: 12-9$

4. Raymond A, Jacob E, Jacob D, Lyons J. Peer learning a pedagogical approach to enhance online learning: A qualitative exploration. Nurse Educ Today $2016 ; 44: 165-9$.

5. Grzych G, Schraen-Maschke S. Outils pédagogiques interactifs: évaluation de trois systèmes pour la formation médicale. Ann Biol Clin (Paris) $2019 ; 77: 429-35$. 